\title{
Hagyomány-kitettség vagy tabutörés ${ }^{1}$
}

\author{
RAJKÓ ANDREA - A. GERGELY ANDRÁS²
}

\begin{abstract}
ABSZTRAKT
Az előadás a zsidó családi nevelés tradicionális és előírásokkal pontosított nevelési rendjében keresi a tradicionális női és anyai szerep szakrális gyökereit, szemben a modernitás női karrier-lehetöségeivel és üvegplafonjával. A női és nevelési kérdések, férfi-szerepek terén értékrendi értelemben házon belüli és házon/családon/háztartáson kívüli világokra bomlik minden, kialakul a férfivilág prioritásainak kapun kívüli, hitéleti érvényesülése, ám otthon lényegében „nőuralom" van a szó konvencionális értelmében. A lányok nevelésére vonatkozó törvényi és háláchikus elöírásokban minden a mentális-morális tisztaság megörizhetöségét szolgálja: legyen a család nukleáris biztonsága zavartalan, a rokonsági rendszerrel fenntartott kapcsolatok kiegyensúlyozottak, a társadalmi integráció folyamata pedig akadálymentes. E szabályrendszer ugyanakkor az alternatív, reform és posztmodern judaizmus hatókörében kibővül a modernitás korának társadalmi marginalizációs, holokauszt-emlékezeti, életmódváltó, mobilitási aktivitásban eröteljesen divergáló törekvések (korosztályi, kapcsolathálózati, felekezeti életbeli, értékrendszeri) eltéréseinek legitimmé válásával, valamint sokszor egyazon társadalmi térben is végbemegy a szekularizálódás, a merev Tóra-követés ellenében a modernitás új ismérveit is figyelembe vevő nézőpontok legitimálódása.
\end{abstract}

KULCSSZAVAK: szakrális hagyomány vagy modernitás, női siker-esélyesség, üvegplafon, mobilitás-feszültség, élethazugság vagy énkeresés, tabu-mentes adaptáció, retardált szocializáció, zsidó női szerepkonvenciók

\section{ABSTRACT}

\section{Sacred-Conventional Roots of Female Roles, or the oppositional women's and the glass ceiling}

The presentation attempts to discover the sacred roots of traditional female and maternal roles embedded in the established, accepted, specified regulations and orders of parenting, as opposed to women's career opportunities and the glass ceiling barrier to advancement present

${ }^{1}$ E szöveg az MTA-SZTE Vallási Kultúrakutató Csoport és az OR-ZSE Kaufmann Dávid Kutatócsoport A család egykor és ma 5. konferenciáján (2018. dec. 10-11., Szeged, SZTE BTK) elhangzott előadás bővített, szerkesztett változata.

${ }^{2}$ Rajkó Andrea PhD., BME Szociológia és Kommunikáció Tanszék, egyetemi adjunktus, szociológus, tabukutató ; A. Gergely András kandidátus, ELTE TÁTK Kulturális Antropológia Tanszék, PDT DTI oktató. 


\section{KÖZELKÉP - Hozzászólás}

in modernity. In terms of value, in the area of men's roles, female and parenting issues get separated into in-house / within family / out-of-home worlds; domination of the male world remains outside and creed related, while at home there is essentially a "female domination" in the conventional sense of the word. Everything in the statutory and halachic provisions for girls' education serves to preserve mental-moral purity in order to protect the safety of the nuclear family; the relations within the kinship alliance balanced; the process of social integration unobstructed. At the same time, these rules are expanding within the scope of alternative, reform and postmodern Judaism; the age of modernity is the legitimacy of social marginalization, postholocaust, lifestyle change, strongly diverging efforts in mobility activity (age group, network of relationships, denominational life, value system), and secularization often takes place in the same social space, the legitimacy of viewpoints that take into account the new criteria of modernity against rigid Torah-tracking.

KEYWORDS: sacred tradition or modernization, women success-chances, mobility, self-searching, jewish women roles

\section{Bevezetés}

Ötödik alkalommal rendezte meg idén az MTA-SZTE Vallási Kultúrakutató Csoport és az OR-ZSE Kaufmann Dávid Kutatócsoport $A$ család egykor és ma konferenciát, melyen a társas-társadalmi együttlét legősibb, legklasszikusabb formájának elméleti, bölcsészeti, történeti, filológiai, szociológiai, vizuális és szakrális alakváltozatai kerülnek szóba. A találkozók anyagai mindegyre meg is jelennek kötetek formájában, így szélesebb publikum is részese lehet a tudományos, kutatási, vallásnéprajzi, filozófiai vagy éppen vizuális kultúra-kutatási áttekintések válogatott szemléjének. Ezúttal mintegy negyvenkét előadás programja kínálkozott a résztvevők számára olyan útkereső tájékozódás tárgyává lenni, melyekből a család ősi, történeti, modern és kortárs alakváltozatai, társadalmi képe, közösségi-nevelési-szocializációs hatása, szűkülése és szétesése, reményei és mindezek értelmezései kaptak hangot a legkülönbözőbb tudományterületek, egyházak, kutatói körök képviselői és témakörei révén. Az értelmezéseket áttekintő szándék itt legtovább úgy juthat, ha kifejezi a kifejezhetetlent: család sokféle volt és lett, lesz és lehet, tűnhetett és tűnt is változónak, változatlannak, szentnek és biztosnak, öröknek és válságban lévőnek, szakrálisnak és szociálisnak - de leginkább a róla mint a társas lét legfőbb tüneményéről való elmélkedés alakváltozatai kerülhettek az előadói és hallgatói látképbe. A középkori dél-francia-spanyol vagy görög drámákban mutatkozó család, a mai nagykunsági vagy izraeli családszervezet, a görögkatolikus egyházi fohászok családja és a még létező kibuc-családok helyzetképe, a családfosztás háborús vagy Soá utáni nemzedékeinek élményközösségei, a konfliktusos és a reménykereső, a festményeken ábrázolt és a történeti jelképekben megmaradó, a nevelésben szerepet kapott és a neveltetésből valamiképpen kieső családmodellek, korosztályi családképek, pedagógiai 


\section{KÖZELKÉP - Hozzászólás}

értékcélok, állami támaszok és ideálok, közösségpótló jelképek szinte követhetetlen kavalkádja volt tehát jelen az előadásokban és képes illusztrációkban. Az alábbi előadás-töredék csupán egyetlen, kissé reflexív tónusú is az elhangzott, megannyi gonddal teli vagy kiútkereső témaválasztás között, s bár a limitált idő mindenkit szorított a rövid, érintőleges közelítésmódra, de a kiválasztott szempontok sokféleségével, vitatható és értelmezésre váró jellegével talán ez a kivonatos áttekintés jelzi is a társadalmi, a közösségi, a szakrális, a problematikus és a megoldáskereső szerepformák jelenkori fogalmi sokféleségét. Ez az előadás (akár vetített-képes, akár hálózati forrásokból vett) illusztrációval, esetleg filmbetétekkel, szövegidézetekkel bizonnyal többet sugallhatna a teljesebb modellekből, de mint valami görcsös tisztázás helyetti, demográfiai táblákkal teli vagy családpolitikai állásfoglalás nélküli kérdésfelvetés is érdemben tükrözi talán a korunkban jelen lévő dilemmák, korkérdések és folyamatok némelyikét...

Első körben már, rövid expozícióként arról, mit is kívánunk mondani, talán megfontoltabb onnan kezdeni: a hazai társadalomkutatások, feminizmus- vagy szakrális reprezentáció-kutatások megannyi értelmezési tér felé terelhetnék a hagyományok szerinti életmód és értékrend, az együtt élő közösségek normarendszere és önképe, vagy szűkebben az állam-társadalom-közösség viszonyrendjének példatárát, ám ezekkel itt most nem kívánunk foglalkozni, ahogyan az egyetemes, európai vagy hazai nőmozgalmak, szüfrazsettek vagy szex-rabszolgák, mereven hierarchizált euro-amerikai vagy „harmadik világbeli” nőpolitikák részkérdéseivel sem. Kutatási fókuszunkba elsősorban azt emeltük, hogy a társadalmi tagozódásban (szociológiai, tudáselosztási, jövedelmi, kapcsolathálózati, szerepvállalási és identitás-problematikákon belül) megfogalmazódó, sokszor kimondatlan mobilitási függésrend miképpen jelenik meg egy tradicionális, sőt ősi örökségét sokféle módon tartósító vallási-kulturális csoport, a zsidóság mai magyarországi normarendjében, s ebben is főképp a kortárs társadalmon belüli női szerepmagatartásoknak kitetten. Vállalva, hogy „avatatlanságunk” nem ellenünk szól majd, illetve hogy kultúrakutatási és szimbolizációs struktúrákban számos (kívülről nehezebben vagy sehogy) belátható dimenzióra - egyebek között kutatásokra, szakrális elemzésekre, judaisztikai vagy etnospecifikus részkérdésekre - kitérni nem lesz módunk az elvárható részletességgel, előadásunk témaköre inkább kérdésfelvető szándékú, nem pedig „elrendező” vagy öntörvényű rendszert kereső és megnevező.

Női szerep és rang, kiszolgáltatottság vagy többre képesség kérdése ténylegesen nem kiemelt alaptémája a zsidóság mindennapi létének és értékrendjének, fóleg nem a tudományos elemzésnek - talán a hazai polgárosodásig és demográfiai szerkezetváltozásokig, sőt a hitéleti szervezetváltozásoknak sem. Azóta azonban, főképp alternatív aspektusból megfogalmazva, vagy a társas viselkedési modellek példatárát figyelembe véve, jócskán és meghatározóan is az. Engedtessék itt egy kontrasztos képet exponálni a közfelfogások és másképp-értelmezések példatárá- 


\section{KÖZELKÉP - Hozzászólás}

ból. Ismeretes, hogy tradicionálisan a zsidó férfiak minden reggel azt imádkozzák: „Áldott vagy, örökkévaló Istenünk, a világ királya, hogy nem teremtettél nőnek”. Lehetne mondani: akár zsidó és nem zsidó feministák, vagy más vallások hívei, esetleg laikus kívülállók egyik hangzatos és folyamatos érve éppen ez áldás zord kritikájában fogalmazódik meg, ugyanis a fohászról alkotható felszínes alapélmény hangozhat akár vádként, mely szerint „a zsidó vallás elnyomja a nőket”, illetve a nőt valami alsóbbrendű, káros lénynek mutatja ezzel. Ugyanakkor több vallásfilozófus/vallástörténész/rabbi sugallta vélemény szerint is a veretes szentírási szövegek alapján kimondható: a „bibliai időkben” a nő szimplán csak „tárgy” volt, idővel később vagyontárgy, s csak jóval azután lett kifejezett érték is. ${ }^{3} \mathrm{~A}$ közbeszédben ma már kihívóbb a nemek közötti egyenlőség szükséges evidenciájára hivatkozó érvelésmód, ami szerint válaszképpen akkor volna a reggeli fohász individuális értékrend alapján jogszerű, ha a nők az ellenoldalon azért fakadnának hálára: Áldott vagy, amiért nem teremtettél férfinak! Csakhogy az áldás női verziója mégis így hangzik: „Áldott vagy, hogy akaratod szerint teremtettél"!

Kicsit árnyaltabb, szakrálisabb, vagy a zsidó életvilág-közeli érvelések számára ennek is gazdagon megvan az alapja, ha másban nem, a korlátozások számossága terén mindenképpen: hiszen a 613 parancs-értékű előírás minden férfira vonatkozik, míg a nőre konkrétan leginkább csak három, miután a hüpe alatt egyezségre szerződött: a gyertyagyújtás, a tésztaáldozat és a mikve használata (lásd pl. Tóth Andrea 2015: 20; Fenyves 2012: 66). A tradicionális értékrend szigorúbb követése és részletesebb judaisztikai bemutatása ezt az „aránytalanságot” nyilván még számossal kiegészítheti, de a kötelmek súlyos tömege látszólag egyenlőtlen állapotot eredményez, s teszi ezt konvencionálisan, sőt értékrendi értelemben is. A kontraszt látszólagos persze, hisz a kóserság, a hitéleti vagy mindennapi tevékenységek végtelenül széles skálája egyaránt kötelez férfit és nőt, amennyiben mindketten a konvenciók követésében érdekeltek, az Ö-való útmutatását és a micvák rendjét követik (lásd Tóth A. 2015; Fényes 2018; Glässer 2012; Hrotkó 2014; Glässer - Zima szerk. 2014; Oláh 2015); de szerepeik mintegy a házasságszervezők útmutatásain, a konvencionálisabb férfitársadalmak értékrendjén, a törvényi szövegek sokaságán túl a származásközösség megannyi normatív hatás együttesével összefonva a szakrális közösségen túli miliőben is jelen szokott lenni. Túl már csak azért is, mert a zsidóság sosem csupán önmagában élet, hanem mindig is interakcióban, kölcsönhatásokban volt társadalmi-földrajzi-szakrális környezetével is, ahol tehát a kötelmek rendje más volt - ha a női szerepfelfogások skálája nem is okvetlenül árnyaltabb.

${ }^{3}$ Persze nem kifejezetten a zsidóság az egyetlen példa erre. A „tárgyiasítás” és a teremtéstörténeti változatok köréhez lásd Fényes 2018; Kelemen 2002, 2012; Külős 1999; Glässer 2015; Fenyves 2012; Hrotkó 2012; Pécsi 2009; Tóth K. 2018; Schweitzer 2016. De lásd amúgy az „asszonyállat” kifejezést a magyar szöveghagyományban is! 


\section{KÖZELKÉP - Hozzászólás}

A férfi és női (következőleg családi, létfenntartói és szimbolikus) szerepek /versus tilalmak/ köre részint talán őrzi, formalizálja, de jelképek során át és tilalmak rendjével együtt is tartósítja a nemek közti különbségeket. ${ }^{4}$ Ámde valójában a zsidó tradicionális gondolkodásban talán sosem volt látványos e nemi szereptulajdonítások efféle rendező elve. A zsidóságon belül, akinek több kötelessége van, mert férfi, annak sosem a „fölérendelt" státus a joghelyzete - sokkal inkább a vállalt-vállalandó kötelezettségek terhe, mennyisége, megkérdőjelezhetetlen funkciója, avagy a teljesíthető jótétemények számszerű többlete. Mármost éppen ezért kérdés a zsidó emancipáció históriájának, a háláchikus normáknak, életvezetési mintáknak jelenkori státusa a megváltozó szereptulajdonítások mai rendszerében és ezek kommunikációs felületi megjelenésében, valamint szakrális dimenzióban is. Sőt: eltérések az európai zsidóság nemi tagoltságát illetően sokfélék voltak és maradtak is, a Soá utáni második-harmadik generáció pedig immár egészen másként tekint a női és zsidó szerepkonvenciókra, mint vállalhatókra vagy megújíthatókra. ${ }^{5}$

Konferenciánkon számos előadás foglalkozik érintőlegesen azzal a tárgykörrel, mely kapcsolódik valamilyen módon a mi probléma-tálalásunkhoz: itt Balázs Gábor, Buk Krisztina, Fényes Balázs, Kelemen Katalin, Oláh János, Gergely Anna témái mintegy kiegészítők, „felvezetések” lehetnének saját kérdéskörünkhöz, föltételezhetően számos adalékkal pontosítva az akut, de szélesebb társadalmi reflexióra is kiható dilemmát. Kulturális kódok, olvasatok, értékminták, modellek a tradíció és a modernitás kettős szorításában, eltérő értelmezési terekben, feltörekvés és női emancipáció értékcéljai között, mindezek megjelenítési módjai és normái hangot kaphatnának rövid felvezetésként, ahogyan az autoritásvesztés, a hagyományos családi funkciók értékválsága és -relativizálódása Lányi Gusztáv előadásában, Singer-regényhősök családhistóriái Hanvay Hajnalka tárgykörében, vagy Kiss Endre Tönnies-prezentációja ugyancsak közelítenek ama problematikához, melyet sokan mások roppant sokféle elemzés tárgyává tettek már. Emlékezetes az immár tizenöt éves $A$ zsidó nô kiállítás katalógusában publikált írások többsége, a Karády Viktor feldolgozta házasságkötések és női továbbtanulási mutatók kérdésköre, a kortárs pályaképek-életutak válogatása S. Nagy Katalin vagy tudományos karrierek historikus megjelenítésével Borgos Anna, Forrai Judit, Nagy Péter Tibor, Hernádi Miklós munkáiban, az indivi-

${ }^{4}$ Lásd még a Bálint Ház Összevont Tanéjzáró programját, Toronyi Zsuzsa muzeológus, igazgató, Magyar Zsidó Múzeum és Levéltár, Horányi Gábor fizikus, igazgató, Lauder Javne Iskola és Balázs Gábor eszmetörténész: Van különbség? És ha nem, miért igen?! A férfi és nő különbségéről szóló vitáját: www. balinthaz.hu/BalintHaz_savuot_2017majus30.pdf; továbbá pl. Maybaum 1884; Oláh 2015; Fényes 2012; Kelemen 2012: 461-467.

${ }^{5}$ Lásd ehhez Szász Antónia pontosítását: „Az egalitárius szemlélet nemcsak a nők, hanem sok férfi számára is szimpatikus. Azok, akik a zsidó tradíció követését hagyományosabb formában, de egalitárius felfogással képzelték el, a maszorti irányzathoz (a 2006-ban megalakult Dor Hadash közösséghez) csatlakoztak, vagy a reform irányzatnál maradtak elfogadó attitűdje miatt" (Szász 2011: 565). Továbbá ide kapcsolódik Ausztrics 2015; Cseh 2015; Mikes 2013; Kelemen 2002; Szász 2008 munkája is. 


\section{KÖZELKÉP - Hozzászólás}

dualizációs és én-stratégiák fiatalok közötti rendszere Vincze Kata Zsófia visszatérők-kutatásában, az EszterHáz Egyesület rendezvényei és kiadványai, Pécsi Katalin kötetei, Kelemen Katalin esszéi és előadásai, Ausztrics Andrea fiatal zsidó önszerveződési színtéren zajló kutatása a Marom tevékenységéről, Cseh Enikő a kortárs francia alternatívákról, Gál Ivetta kutatása a Dózsa György úti közösségről és a nők közös térben létéről, Papp Richárd elemzése a Bethlen tériek női szerepfelfogásáról, Mikes Hanna zsinagógai, vagy Zimre Fanni női szerepeket és identitás-közvetítő magatartásokat vizsgáló terepkutatása (konkrétan a Chábád foglalkozásain), s még roppant sokféle forrás lenne fölsorolható, melyek megidézik akár az anya-szerepeket, gyermeknevelési elveket, a tudományos pályák nőképét és a nemek arányát, az önszervező értékterek kialakulását vagy alternatíváit körvonalazva. Mindezek (még „népszerúsítőbben fogalmazva”) szinte kihívásként vannak jelen a feltörekvési, mobilitási szerepstratégiákban, ha a sikerképességek, adottságok, lehetőségek körét és „üvegplafonját” tekintjük.

Márpedig ezt tekintve nem lehet szem elől téveszteni az olyan értelmezési módokat, amilyen például a Hanna Női Klub szereptudatosító törekvése, a Chábád Alef Kids programjai, ${ }^{6}$ a női és férfi résztvevőknek szóló oktatások elkülönítése, vagy akár a nők és a társadalmi mobilitás témaköre, melyek egyik látványos prototípusát Mireille Guiliano A francia nők karriert csinálnak kötete mutatja fel - korántsem kivételességgel.7 Ebben a sikerképes női modell eleganciáját, az amerikai és francia pályaképek distanciáit, valamint a feltörekvés eltérő modelljeit fogalmazza meg, éppenséggel ellene szólva a „sikernő” korlátozhatóságának. Itt a „nemzeti” karakterisztikát használja életmód, életszervezési rutin és közfelfogások kortárs mintakészlete szerint, de éppenséggel létezik számos vallási csoportozat, ahol a női mobilitást a rituális élet, a szakrális normarend korlátozza evidens módon. De fennállnak az ellenoldali kísérletek is: például mintegy öt esztendeje létezik és hatásos múködésben mutatkozik (Bálint Házban és a Facebookon, de blogon és másutt, pszichológiai, irodalmi, kultúratudományi, szociológiai, kommunikációs színtéren is) az a közéleti csoportozat, mely a nők egyenjogúságának „örökzöld” témakörével hergeli vagy nyugtatja a közvélekedést. Viták, tisztázó eszmetársítások, filmek, gender-témakörök foglalkoztatják e kényszer-helyzeteket elfogadókat, avagy egyegy tipikusan „női” életútra rátérőket, a nemek közötti szereptulajdonítások sémáit eltűrőket és nyilvános mutatkozásaikra rábíró problémafelvetóket. A nemek közötti egyenlőségi játszmák évszázados témaköre és a kortárs európai adatsorok vagy kimutatások többsége szerint nemcsak a „tárgyiasított női szerepekbe” szorultság válik mindegyre súlyosabb kihívássá - lényegében világszerte -, hanem az „Üvegplafon", a nőkhöz kapcsolódó nemi sztereotípiák következtében lejátszódó hátrányos

\footnotetext{
${ }^{6}$ http://zsido.com/kozosseg/hanna-noi-klub/

${ }^{7}$ Guiliano, Mireille (2010): A francia nők karriert csinálnak. Munka, értelem és érzelem.
} 


\section{KÖZELKÉP - Hozzászólás}

megkülönböztetés, a társadalomtudományok eszközeivel megrajzolható férfi és női életmód, értékrend, nevelés, karrier-lehetőségek, tanulmányi esélyek, fizetések, családban elnyerhető kapcsolati státuszok aktuális kérdései is egyre inkább témává válnak. Az Üvegplafon-esteket meghirdető-szervező filozófus és média-eseményeket organizáló elméleti szakemberek, érdekképviselők ama kérdéssel foglalatoskodást szorgalmazzák, hogy „milyen tipikus problémákkal kell a nőknek szembenézniük, és hogy hogyan segíthet a társadalom és a politikai döntéshozatal a nemek közti elfogadhatatlan különbségek mérséklésében”. Gát Anna és Réz Anna kihívó „női közéletmód" magazin-műsorai részben érintik a zsidóságukat is vállalókat, s ennek az online és offline tevékenységnek alapcélja, hogy „túllépjen azon az - elsősorban budapesti - értelmiségi niche-en, amely most elsődleges közege a feminizmusról szóló beszédnek" és a magyar nők európai értelemben véve katasztrofális helyzetét nehezményező interakciót vállalják mindezzel. ${ }^{8}$ Kicsiben és helyiben, de törekvésük emlékeztet a 60-as években Betty Friedan megalakította „Nemzeti Szervezet a Nőkért” mozgalomra, „A nő mint zsidó, a zsidó mint nő” kezdeményezésre - nem tisztán feminizmusra, hanem etnofeminizmusra és civil ellenállási mozgalomra is a megértés/megértetés érdekében. ${ }^{9}$

Fennáll tehát egy alaphelyzet, melyben konvencionálisan megvan a nő mint zsinagógai szereplő kijelölt helye,$^{10}$ nem hívható föl a Tórához a szertartási kommunikáció színterében, nem számít bele a minjen létszámába, elkülönítik a zsinagógai térben is, ${ }^{11}$ egy szukkoti vacsorán is külön esznek a férfiak, s külön a nők, továbbá családi szerepe a nőt egy múlt időhöz köti strukturálisan, ugyanakkor épp jelenkori társadalmi szerepvállalásai, mutatkozásai lesznek látványosan kihívóakká, az üvegplafon létét konvenció révén szükségképpen elfogadóvá - de a tabudöntés és plafontörés kontextusában ugyanakkor mindezt jócskán meghaladóvá. Hol hát a mobilitás-határa „„ölfelé” a női karriernek, a pályaorientációs, feltörekvési aspirációknak, ha a főszereplő éppenséggel zsidó női szereptudattal, neveltetéssel, szabály- és

\footnotetext{
${ }^{8}$ Németh Vályi Klári interjúja, Szombat, 2016.

${ }^{9}$ Betty Friedan a 60-as években alapította a National Organization for Woment (NOW) Nemzeti Szervezet a Nőkért) és 1970-ben szervezte a nők sztrájkját az egyenlőségért. 1993 augusztusában, 50. évfordulóján annak, hogy a nők kivívták maguknak a szavazati jogot, Friedan 50 ezer nőt (azért több száz férfi is volt közöttük) vitt ki a Fifth Avenue-ra tüntetni. 1984-ben ő volt a vezérszónoka a „A nő mint zsidó, a zsidó mint nő" témájú konferenciának. Zsidó identitását illetően - talán meglepő módon - így nyilatkozott: „Női identitásom meghatározása sokat segített nekem abban, hogy megerősítsem zsidó identitásomat. Szembe kell nézni a zsidó hagyományok nőellenes aspektusaival ahhoz, hogy elfogadhassuk mind a feminizmust, mind a judaizmust". https://www.szombat.org/archivum/nehez-egyutteles-feminizmus-es-judaizmus

10 „Ebből következően a zsinagóga bejárata a szemben lévő oldalon legyen; a férfiakat és a nőket el kell különíteni, hasonlóan, mint a Szentélyben annak idejében" (Misna: Midot II,5 és Talmud: Szuká 51b. utalja Oláh 2015: 2).

${ }^{11}$ Lásd: Oláh 2015: 2-3; valamint A nôi ima ereje: http://sofar.tudozsido.com/a-noi-ima-ereje/. Sófár, 2008. december 19., továbbá: https://www.youtube.com/watch?v=iZf5HpXVl4k
} 


\section{KÖZELKÉP - Hozzászólás}

értékrendszerrel él? S mi szab határt annak, hogy fennebb jutva a társadalmi létrán vagy presztízs-lépcsőn, magára vegye a sikerképesség legfőbb attitúdjét, a reflexivitás mellett a karrier-építési rugalmasságot, ráadásképpen a gyermekét egyedül nevelő anya szerepkörét, az elhagyottét, a családfenntartóét, a férfi-státuszba átkerülőét, az életmenedzselőét?

Voltaképpen egy kulcskérdés kiemelése fontos csupán itt: van-e a háláchikus létmódnak, konvencionális, tradicionális normarendnek és fóképpen családi nevelésnek hatása, összefüggése a nők társadalmi szerepfunkcióival, a kortárs sikerképességgel, a női önérvényesítés rangtöbbletével..? Többlet-e a női szerep „általános”, hagyománykövető vagy ortodox változata, és specifikus-e a zsidó női szerep, akar-e és tud-e ez érvényesülni, vagy konvencionális „elnyomás” alatt áll évezredek óta? Avagy mit jelent nőnek lenni a zsidóságon belül: kevesebb tradicionális beleszólást a lét kérdéseibe, több rangot a "mamele” funkciójában, megkötöttséget az életvitelben, a társadalmi és nemi szerepek teljesítésében, a családi nevelésben és értékrendben, s emögött, emellett még terheli-e például válás esetén a magányon túli „családfői” teher átvétele is, s emiatt el lehet-e válni egyáltalán az életvitel-szerűen hithű nevelési normák felrúgása nélkül, lehet-e válni a férj cselekvő akarata és a get (elbocsátó okmány, válólevél) nélkül, lehet-e belülről áttörni a többszörös üvegfalakat vagy plafonokat, s mindezzel együtt ilyenkor veszít vagy nyer az önérvényesítő nő, s miként alakul a tágabb társadalmi közfelfogáson inneni, zsidó közösségi értékrenden belüli megítélése..? Ehhez persze van bőven háttérirodalom, ugyanakkor nincsenek kellő számban interjúk és megfigyelési tapasztalatok, (bár áttételesen mégis létezik számos ilyen, de nem az „üvegplafon” dimenziójában), így csak indirekten lehet közelebb jutni a részválaszokhoz.

Egyik részválasz az alapkérdésre /persze szándékos leegyszerűsítésben/ a tradicionális (ebben látványosak Hrotkó Larissza, Fényes Balázs, Papp Richárd, Zimre Fanni, rebecenek nyilatkozatai és nyilvános mutatkozásai, Fényes Balázs, Oláh János, Tillmann 2009, stb. meglátásai); a másik választípus az én-kiteljesítő, társadalmi szereptudatos, struktúra-átrajzoló, posztmodern státusz-reprezentáció (Tóth Katalin, Vincze Kata Zsófia, Ausztrics Andrea, Surányi Ráchel, Susán Eszter, Gantner B. Eszter, Groó Diana, Pécsi Kata, Vasvári Louise, Angelusz - Tardos stb.). További tagolási lehetőség rétegzi ezt a felosztást részint korosztályi, részint zsidó szubkultúra-függő válaszlehetőségekre (lásd például Kelemen Katalin vagy Fenyves Katalin markáns álláspontját a kulcskérdésekben), másik metszet valamelyest térségi bontásban is mutatkozó eltérésekre, történeti kihívásokra figyelemmel hasonlóképpen valamiféle struktúraként tekint minderre. Határozott álláspont tükröződik Fenyves Katalin habilitációs értekezésében is, mely szerint a hazai zsidóság nyelvi asszimilációs alkalmazkodása, a Numerus Clausus folyamata, a mindegyre szorongatottabb státuszba kerülő társadalmi tömeg valójában már az 1920-30-as évektől átélte a nők képzésének, társadalmi befolyásának, presztízs-csökkenésének és 


\section{KÖZELKÉP - Hozzászólás}

mobilitási korlátozásainak következményeit (Fenyves 2012), de ehhez elementáris módon kapcsolhatónak láttatja a korábban már elért státusok megszúnését, a női imakönyvek megjelenésétől és a főkötő/paróka vitától a zsinagógai karzat-rács-jogosultságok variációiig, a zsidó családok átalakulásától kezdve a matriarchátustól a patriarchátusig zajló szerep-átrendeződés részkérdéseit is (vö. Fenyves 2012; Hrotkó 2014b). Mindeközben nemcsak a társadalmi átrétegződés ment végbe a 19-20. század fordulóján, hanem a képzettség, társadalmi mobilitás, elfoglaltság, zsinagógák kiüresedése, születésszám-csökkenés, a nőkre vonatkozó korlátozások lassú felpuhulása, presztízs-pozíciókba kerülésük megsokasodása (pl. egyletekben, tudományos vagy művészeti területeken, immár a lakásokból kiszabadulva), sőt a szakrális hagyomány ellenében a polgári szerződésjogok érvényesülési feltételei is hatottak arra, hogy a zsidóságon belül mintegy evidenciának számító kérdésekben az ortodox és neológ szemléletmódok megütközzenek, eltérő következtetésre jutva a női szerepek, karrierek és legitimációs szertartások vagy tabuk terén. „Az elmúlt századokban gyökeresen megváltozott a házasságjogi és családjogi törvénykezés, a házasságkötések törvényi szabályozása. A család és családtagok szerepe az értékrend őrzésében és átadásában alapvetően más lett. Többgenerációs családok ma már ritkábban élnek együtt, a kiscsaládok dominálnak. Ennek megfelelően változó a nevelési és oktatási intézmények (bölcsőde, óvoda, iskola) és a család kapcsolata, viszonya. A 19. század új nemzeti mozgalmai is felvázolták a következő nemzedékek és az őket kibocsátó ideális család vízióját. Erre az időszakra tehető a nőkép, a női szerepek átalakulásának kezdete is." (Kiss Endre - Barna Gábor 2014: 7)

A női szerepfelfogások és a nőkép-változás egyik triviális kommunikációs felülete a bulvár-médiából visszaköszönő emancipációs igény, a szélesebb közvélekedésben is megjelenő szerepstruktúra-változás, (amúgy az „ideális család-vízió” részeként tekintve magát a családi köteléket is), valamint épp az érintett nők én-érvényesítési szereptudatosságának nagymértékű növekedése is. Ám ez utóbbi vállalásában részint a „feminizmus-gyanús” mutatkozások széles köre is megbúvik, de közelebbről nézve rátalálunk a norma-átrendeződések, szereptudatok, önérvényesítési stratégiák, továbbá tabukezelések és tabutörések mechanizmusaira is.

A Rajkó Andrea kezdeményezte kutatásban a normák, tiltások, tabuk sok esetben eredeti társadalmi funkciójukat elvesztett fogalmak jelentéskörében is feltűntek (érdemes itt az egyedülálló szülő családmodelljére vagy az abortusz témakörére gondolni), de a tabuk funkciói között sokszor elsősorban mint pozitív értelemben tárgyalt segítő, támogató, védelmi funkciót értelmezzük az új értékrendek tükröződéseit, amelyek a magatartást, cselekvést, viselkedést segítő szabályrendszerként működnek. A tabuk lényeges társadalmi feladata lehet az is, ha hozzájárulnak a társadalmak és a társadalmi csoportok, valamint egyének stabilitásához, védelmező funkcióval is bírnak, biztosíthatják a társadalom múködését pusztán azáltal, hogy mellőzik vagy elfedik azokat a dolgokat, amelyek fenyegetést jelenthetnének az 


\section{KÖZELKÉP - Hozzászólás}

egyén vagy csoport pozitív identitására vagy életkilátásaira. Ezzel mintegy rejtik a saját élettörténet sötét oldalait, a halált, a betegséget vagy az élet értelmének kérdéseit, az egyéni megbirkózási mechanizmus formáit, az egyéni és kollektív identitás felépítésének sajátos stratégiáit, vagy lefedhetik mindazt, ami egy társadalomban potenciálisan nem lehet szembesülés, identifikációs konfliktus tárgya, vagy a korszak társadalmi közbeszédének mintegy „letiltott” tematikája, és párhuzamosan kibeszéletlen öröksége is. Ennek a narratív feszültségnek lehetséges következménye, hogy ma is a társadalmi tabuk egyike a zsidósághoz való viszony, s az antiszemitizmus újbóli erősödése (az 1990-es évektől), ami még inkább készteti a téma tabuizálását, a sokféle köznapi kommunikációban vitatott, kibeszélt vagy körülértelmezett témaként megjelenését. Ennyiben komplex társadalmi termék is a tabu, de előfordulhat, hogy csupán egyfajta személyes érzelmi idegenkedés a felmerülő cselekménnyel kapcsolatban, vagyis nagyon nehéz konszenzusra jutni már a fogalom definiálásakor is, miközben elméletileg maga a tabusított kifejezés (látszólag) mindenki számára ugyanazt jelenti: rejtettet, titkot, titkolandót, kibeszélhetetlent, elhallgatásra ítéltet. Ezenközben épp a határfogalmak és/vagy kommunikációs helyzetek helyettesítik sokszor a tabu fogalmát: ilyenek példaképpen a hallgatás, elhallgatás, illetlenség, magánügy, elhatárolódás, csönd, norma, titok, szabály, erkölcstelenség. Mindegyik kifejezésben egy konkrét folyamat a közös: a tiltás, amely lehet külső és/vagy belső motivációjú. A tabusítási mechanizmus a vizuálisan és (generációs, életkori sajtosságként is értelmezhető módon) kulturálisan elvárt külsőségekre vonatkozó normalitás, valamint az adottságok, ízlés, szocializációs, szokásbeli stb. különbségekből fakad: „Látjuk, de nem beszélünk róla.” (Rajkó 2015: 83)

A kibeszéletlen tabu-területek és elemzési témakörünkbe illően (Rajkó Andrea tabu-kutatása révén, és részben kommunikáció-kutatási szakirodalmi áttekintés alapján) megállapíthatjuk: „a társadalmi feltörekvésben, szerepviselkedésekben megmutatkozó fogalmak és normák közül meglehetősen erőteljesnek látszik a tabukat körülvevő értékrendszerek ama tulajdonsága, hogy mivel vannak közös hiedelmeink, szociális konstrukcióink, ezek képesek (inter)akciókat, szertartásközösségeket, élmény- és vélemény-csoportosulásokat kialakítani. Ezekben megjelenik a szociális hűség, amelynek vállalója hajlandó a saját érdekeit, attitűdjeit a közösség érdekei mögé helyezni, a kulturális folytonosság fennmaradásának és a többségi vélemény tiszteletének kifejeződéseként konform magatartást, az utánzást, egyfajta torzítatlan mintakövetést megvalósítani vagy értékesnek minősíteni. A tabunak vélt cselekvés- és viselkedésmódok e szabályok mentén alakulhatnak, sokszor öröklődhetnek, akár több generáción keresztül is. Feltételezhető, hogy a tabu létezését csupán megszegése teszi láthatóvá és észlelhetővé, de a következményektől, szankcióktól való félelem meghatározó eleme a tabu kialakulásának, a tabuszegés jelentőségét pedig az adja meg leginkább, hogy mennyire és hogyan alakítja az ember vagy közösség életét. Különbséget kell tenni azonban a narratív struktúrákban képződő, tila- 


\section{KÖZELKÉP - Hozzászólás}

lommal megtámogatott, szóban átörökített, megtűrtként 'elfogadott', szakrális kinyilatkoztatásokkal vagy szokásjoggal 'védett' és más, például írott, legalizált, mitikus tabuk kezelése között" (Rajkó 2016a: 37-38). A tabuk imígyen a zsidó gyermeknevelési konvenciók, ősi forrásokra hivatkozások, modern átértelmezések és egyedi, nem-konvencionális interpretációk sorában, a gyermeknevelés folyamata során alkalmazott „efféle homályos imperatívuszok révén formálódnak, internalizálódnak. Így aztán a jogi szabályozás és a hivatalos szankciók gyakran feleslegessé is válnak. A verbális (kommunikációs) tabuk speciális funkciói a nonverbális (cselekvésekre vonatkozó) tabukéhoz képest többek között lehetnek a betegség, a test, az öregség, a félelem és elutasítás érzése, a lelki problémák 'kiteregetése' vagy épp pszichológiai kezelése, a stigmatizáltság élménye, a szexualitás, a melegség, és szélesebb körben értve a verbalitás nagy mértékű korlátozottsága a kommunikatív szférában..." (bővebben lásd Rajkó 2016b: 47-48, 74).

Mindez nem jelenti azt, hogy mert a társadalmi vagy közgondolkodási térben jelen van az üvegplafon képzete és élménye, ez mintegy természetes módon jelen kell, legyen az egyházak hierarchiáiban, a vallások normarendjében, a hitéleti törvényekben vagy magatartás-szabályozó értéknormákban is. Ez tehát vitatható valamenynyire, ám amiként a tudott/ismert üvegplafon kérdése nem jelenik meg a muszlim vagy a katolikus, a vaisnava vagy sintoista egyházi normarendben, hitéleti szabályozásban és értékképzetekben valamely látványos formában, annyival inkább jelen van, kifejeződik, hangsúlyt kap a zsidó életviteli szabályok között. Tehát mintegy kontrasztképpen a történeti, családfelfogási, normakövetési vagy családfenntartói szerepfelfogások okán érdemes a másik szférát is aprólékosabban megvizsgálni - ha nem is épp a közgondolkodás vagy a nőmozgalmi értékcélok közvetlen megidézésével.

Mint arra Hrotkó Larissza is több írásában fölhívja figyelmünket (2012, 2014a, 2014c), hogy ezek az anyaszerepek, nőfelfogások, mintaszolgáltató státuszok terén is folyamatosan kérdésekként megmaradó tünemények nem egyszer a nők kitérését, önálló mozgalmi szerepváltását, de ezek mellett is sokszor normatív értékrend-váltását tükrözik: „Mai zsidó nő - akár vallásos, akár nem - az aktuális önkép kialakításában a hagyományos, sőt ortodoxnak nevezett mintából indul ki. Vagy úgy, hogy hátat fordít a rabbinikus hagyománynak, vagy újra értelmezi a férfiak által megfogalmazott hálachikus elő́rásokat. (...) A halachikus minták ma is hatnak a zsidó szocializációs normákra, noha ez néha feszültségekhez vezet” (...) „A traktatusok szövegeiben említett férfiak meghatározták a zsidó nők szerepét és magatartását, vagyis a női szocializációt. Ennek következtében a nők közösségi helyzete a kiskorúak státuszával egyenlő, akik helyett apjuk hozza a döntést”. (...) „[A] Talmud zsidó bölcseleti értelmezésének tükrében a nő szerepe a családi térben jelentőséggel bír. Ám minden verbális csinosítás ellenére a családi teret a társadalom a közélethez képest mindig és mindenhol másodrendűnek értékelte, az anyagi jutalmazás 


\section{KÖZELKÉP - Hozzászólás}

tekintetében is”. (...) „Hivatalos polgári szemlélet alapján a nő 'ugyanolyan ember', mint a férfi, de mégis Más. Tény, hogy a talmudi irodalomban a nő minden esetben a diskurzus tárgya, nem pedig alanya”. (...) „A férfiak által összefoglalt halachikus előírások megszabták a női egzisztencia minden egyes mozzanatát, beleértve a nők öltözködését, a menstruáció, a terhesség és a szülés alatti (utáni) magatartását és az ezzel kapcsolatos higiéniai intézkedéseit. Ezek az előírások mindenekelőtt a férfiak és az utódok rituális tisztaságát biztosították. A vallási vezetők azt magyarázták, hogy a szabályok megtartása az egészséges utódok érdekét szolgálja. A nők, akiknek értéke sokban függött világra hozott utódok számától és minőségétől, érthetően fontosnak tartották a szabályok teljesítését. (...) A hagyomány ugyanis a női testet teszi felelőssé fogantatásért és a magzat egészségéért. A terhes nő környezetét is misztifikálták, ami újabb feszültségeket és félelmeket idézett elő az eredetileg talán nem is annyira félénk női pszichében. (...) A zsidó vallástörténetben a család sohasem volt magánügy, és a mai valóságban sem kizárólag személyes kérdés. (...) A család és a társadalom közötti különbség, hogy a társadalom alapja nem a szexuális kapcsolat, de a nemiség a társadalomban is meghatározó szerepet játszik. A hagyományos zsinagógában a fiúk felnőtté avatása döntően eltér a lányok avatásától, ami mintegy meghatározza felnőtt nemi szerepüket. A zsidó nők számára a család ma is az egyetlen legalizált életviteli minta. A női függetlenséget, esetleg családon kívüli életformát, vagy a nem-hagyományos, hovatovább egynemű partneri kapcsolatot a zsidó társadalom hallgatólagosan eltűri - vagyis a tabu fentebb említett védelmi funkciója itt is érvényesül. A legitimáció feltétele ugyanis, hogy a nő a törvényhozó férfihatalom szabályait megtartja. Valóban természetes nemi hatalomról van itt szó? Vagy nemiségük révén hatalomra jutott maszkulin egyének uralmáról? Hiteles és teljes ember-e az a férfi, akit a társadalomban hatalmi pozíciójával azonosítunk? Feministák és férfikutatók úgy vélik, hogy ez a fajta maszkulinitás nem fejezi ki a férfi igazi természetét. A társadalmi szerep lassan kilép az eddigi nemi keretből, mit sem veszítve nemiségéből. Vajon milyen hatással lesz ez a zsidó családi státuszokra." (Hrotkó 2012: 51-54) A hasonló, belülről átértékelődő folyamatról további részletekkel szolgál habilitációs előadásában is a bevándorlók, a státuszválók, a „nélkülözhetetlenek" témakörében (Hrotkó 2014c).

E téren nemcsak a társadalmi szerepmodellek kortárs esélyei érdemesek vitára (lásd pl. Angelusz - Tardos 2002, Acsády 2002; Bódy 2008; Vincze 2013, 2010), nemcsak a női szerepről az ókortól napjainkig fölvázolt számtalan verzió színezi a körképet, de karakteres például a női sors és a holokauszt, a pszichológia és feminizmus viszonyrendszere (Kende 2008; Pécsi 2009, 2013; Kelemen 2012; Hrotkó 2014c; Cseh 2015; Dalsace 2006), továbbá Louise Vasvári szereptudata és „genderizmusa" a másság vállalásával, ${ }^{12}$ sőt megvan ennek alapkérdése például a magyar

${ }^{12}$ https://www.szombat.org/archivum/a-noi-kultura-mas-mint-a-ferfikultura-avagy-mit-tud-afeminista-nyelvtudomany 


\section{KÖZELKÉP - Hozzászólás}

zsidóság száz évvel ezelőtti orthodox-neológ csoportvitáiban, s attól kezdődően akár mindmáig is. Az utóbbiak áttekintését részben elvégző Schweitzer Gábortól idézzük: „Miért fontos a férfiak és nők zsinagógai egyenjogúságán alapuló egalitárius szemlélet elfogadása? A nők egyenjogúsítása a neológia fennmaradásának egyik záloga. A hitélet fenntartása, illetve megmentése aligha képzelhető el a nők egyenjogúsága nélkül, különösen ott, ahol nem biztosítható tíz felnőtt férfi jelenléte az istentiszteletek megtartásához. A nők hitéleti egyenjogúsítása a neológia megújulását is maga után vonja, miközben a micvákhoz való hozzáférés lehetőségét is kiszélesíti. A női egyenjogúsítás eszméjének elfogadását megkönnyíti, hogy tórai rendelkezésekre vezethető vissza: 'És teremtette Isten az embert az ő képmására, Isten képmására teremtette őt; férfinak és nőnek teremtette őket' (1 Móz. 1: 27). Az egalitárius felfogást mellesleg nemcsak a reform judaizmus (reform judaism) fogadja el, hanem a neológiához közelálló konzervatív zsidóság (conservative judaism) döntő része is egalitárius alapokra helyezte múködését". (Schweitzer 2016) ${ }^{13}$

Csupán a fennálló kontraszt kedvéért hadd idézzük fel továbbá Tóth Katalin öszszehasonlító kutatását, ${ }^{14}$ aki immár nemcsak négy-öt zsinagógai közösségben vizsgálódott, hanem más vallási (kistelepülési katolikus) színtérrel is összehasonlította a mikroközösségi jegyeket. Elemzésében, melyben arra fókuszál, hogyan hatja át a vallási kultúra egészét a szimbolikus interakciók sokasága, érzékletesen kifejti, hogy a tekintély, hatalom és vallási konvenció kérdésköreit empirikus összehasonlítással tekintve (ha talán nincs is a női szerepmódosulásokra vonatkozó részletes háláchikus szabályozás a zsidó hitéleti forrásművekben), de jellegadó, hogy a legtöbb zsinagógai közösségnek, irányzatnak megvannak a saját elképzelései a nők szerepéről, s a nőknek is az ebben való viselkedésről. Tapasztalatai szerint eltérőek a női szerepek a zsinagóga belső terében (elkülönült erkélyen, függönnyel elválasztva, vagy közös térben, de hátra szorulva), a mindennapi vagy ünnepi cselekvések sorában is karakteres a női funkció másodrangúsága, a zsinagógán vagy akár családokon belüli adaptációs különbségek is hangsúlyosan jelen vannak. Mindez a hagyománykövetés, a hagyományteremtés és a progresszív változatok felfogásmódjaiban nemcsak a hazai és európai zsidóságot tekintve eltérő értelmezéseket érdemelt ki, de - tegyük hozzá - tükröződik a mindennapi életben, csoportközi kommunikációban, szokásjogokban is, nem mellesleg még a zsidó házasságközvetítők partner-kínálatában, a temetési szertartásszervezésben, a parókakészítésben, a kóser konyha vitelében, a macesz-beszerzés intézményi mögöttesében is éppúgy helyet kap, miként Singer ko-

${ }^{13}$ https://www.szombat.org/politika/schweitzer-gabor-halado-zsidosag-halodo-zsidosag

14 Tóth Katalin 2018: 107-125., továbbá megjelenés alatt egy terepkutatási napló-anyaga is a bár micvó ünnepéről és eseménymenetéről... Ide is tartozik Tóth Katalin megjegyzése az ortodox/neológ történeti vitához kapcsolódva: ma már nem az ortodox-neológ csoportviták kerülnek előtérbe, hanem a neológia megosztottsága, különböző csoportjainak különböző véleményei a nők - főként zsinagógai helyzetéről és szerepvállalásáról. 


\section{KÖZELKÉP - Hozzászólás}

rai regényeiben, Ostrovsky kárpátaljai vagy Babel ogyesszai történeteiben, s akár a Magyar Zsidó Nő századelős hetilapban..$^{15}$

A zsinagógai tér és a társadalmi tér ekképpeni „megfeleltetését” persze szinte minden jártasabb beavatott félreértelmezésnek tarthatná - ha ugyan nem a családi szerepek, a szakrális előírások és a praxisjogok terén a legtöbb korábbi gyakorlatot meghaladni és „felülértékelni” próbáló reformjudaizmus híve. E kortárs (bár jelentős történeti előzményekre építkező) felfogásmód talán egyik legmerészebb vállalása a női szerepek átértelmezése. Kortárs magyar kutatójukat idézve: „A reform mozgalom elkötelezett a nemek és minden ember teljes egyenjogúsága mellett az élet minden területén. Ebből kifolyólag emancipációt hirdet a zsidó hitéletben is: egyenlő jogokat és kötelességeket biztosít a férfiaknak és a nőknek, a papi és a nem papi származásúaknak egyaránt. A nők is betölthetnek bármely közösségi vagy zsinagógai posztot, lehetnek kántorok, rabbik, közösségvezetők, a Tóra tudós magyarázói. Egalitárius felfogásukból adódik a liturgia megváltoztatása. Szövegszinten a nemi státuszra vonatkozó részeket kihagyják, vagy módosítják. ${ }^{16} \mathrm{~A}$ nők is beleszámítanak a minjánba (a tíz imádkozó ember közösségébe), magukra vehetik az imasálat és az imaszíjakat, nem kell elkülönülve ülniük a férfiaktól felmehetnek a Tórához. A férj és a feleség vallásjogilag is egyenlő." (Szász 2011). E reformszemléletű és modernizált értékrend nemcsak szervezeti értelemben hozott újítást (lásd ehhez Szász 2002, 2008, 2011, 2013; Kelemen 2002, 2012; Ausztrics 2015), vagyis hozzájárult a Bét Orim, Dor Hadash, Marom és más maszorti irányzatok erősödéséhez, hanem a hazai zsidóságon belül is jelentős létszámarányokban képviseli az alternatív szellemiség térhódítását is. Sőt az intézményes feltételek és újrakonstruált tradíciók mellett talán nem lényegtelen szempont, melyet Kelemen Katalin közösségében idézett föl saját betérés-történeti élményéből egy interjúalany: a holokauszt utáni második nemzedék már koedukált iskolákba járt, a szülói mintákban sem volt deklarált és konvenciók szerinti a férfiuralom evidenciája, így sokkal életszerübben elfogadhatóvá vált a női-férfi egyenlőség kérdése (hivatkozza Szász 2013: 94), ám az is nyilvánvaló, hogy mindezt a reformer felfogást és értékrendet meglehetősen sok ellenző hang utasítja el (uo. 84).

A tórai eredetű és konzervatív felfogások alternatívájaként egzisztáló reformszemléletű hívőközösség, az isteni parancsolatok értelmezésében aktív szerepet vállaló női szerepfelfogás emancipatív és résztvevői megjelenítése bár korántsem csupán a kétezres évek hazai törekvéseire jellemző, a női szerepek egyenrangúsá-

15 „[A] nők „Izrael papnői, házi tűzhelyünk őrei” - lásd ehhez Fenyves Katalin 2012; valamint Fényes 2012: 226-227.

${ }^{16}$ A hagyományos imarendben a férfiak azt mondják: „Áldott vagy Te, világ Királya, aki nem teremtettél nőnek”, míg a reform zsidó férfiak és nők: „...aki kedvére teremtett”. A „minden férfira” mondott áldásokat „minden emberre” mondják. Az „Ábrahám Istene” megnevezés helyett az „Ábrahám és Sára Istene" kifejezést használják. 


\section{KÖZELKÉP - Hozzászólás}

gának ekkénti képviselete vallásjogilag is egyenlő jogok és kötelességek rendszerére támaszkodik (ide értve a válás kezdeményezésének jogát, a gondoskodás és házastársi szerepek egyenjogú vállalását, az egyházi szertartásokon belüli szerepvállalások rendjét, stb.), ${ }^{17}$ mi több, már a reform-rabbik jó egyharmada is nőkből áll. Mindez nem teszi fölöslegessé a kérdést: a modernitás szellemében szerveződő női szerepfunkciók nem tisztán tabutörő vállalások-e, s a konzervatív hitközösségi szerepvállalások mellé nem csatlakozik-e immár növekvő arányban a szakrális tabukkal szembeni kommunikatív identitás? A lehetséges válaszok sokféleségéből csupán kiemelni lehet Glässer Norbert elemző áttekintését a hagyományos szerep-interpretációk elmúlt száz-százötven évéből, melyben az orthodox és a modernizációs felfogások egyik különbségét az európai kultúra-fogalomra vezeti vissza, jelezve azt is: a hagyomány értelmében nem a „kapni”, hanem az adni a zsidó konvenció, de nem az átadás, hanem az átvétel képviseli a kulturális mintázatot, így a Szináj-hegyi örökség önmagára nem mint kultúra-átvételre gondol, hanem kultúraként a kívülről jöttre, az európai szekularizáció eszméihez kötődés elemeire utal (Glässer 2012). Ebben például az orthodoxia létszámcsökkenése, a Trianon után határokon kívülre került képző intézmények, majd erre következően a családi nevelési elvek részbeni változását „a külvilág árvízveszedelme” is okozhatta, de szerepet kaphatott a vallási szocializációra háruló felelősség, a Sulchan Aruch útmutatásaitól el nem térő anyai szereptudatosság vállalhatósága, az orthodox sajtó nőknek szóló cikkei, a törvényileg bevezetett polgári házasságkötés normarontó hatása, az elveszett házassági szerződések, a megváltozó közerkölcs valláserkölcsi hatása, a házasodási életévek kitolódása, de a Monarchia-kori zsidó élet iránti nosztalgia erőteljes fogyatkozása is (uo.). A múlthoz és jövőhöz való viszony modern és premodern indikációi között nemcsak a generációk közötti „vallástalanodás” folyamata, az ősök örökségét átértelmező és újragondoló korosztályok választási stratégiái kaptak szerepet, hanem a hagyománykövetés és a kontinuitás-fogalom átalakulási sodrása is: a Tóra- és hagyománykövetés láncolata a fogyatkozó vallásosság, a vegyesházasságok, a polgári és műveltségi hatások, az írott és szóbeli Tan mintázatainak fokozatos elérvénytelenedése mind-mind hozzájárultak az orthodoxia örökségének minőségromlásához, ezen belül az anya-szerepek, a mintaszolgáltató vallási nevelési elvek, a tekintély és az intézmény megmaradási feltételeinek átalakulása, az erősödő individualizáció hitgyakorlati hatásai is (uo.).

A zsidóságot „életproblémaként” átélő (két világháború közötti) tudományosművészeti elit is számos példával jelzi a külső kulturális (éppenséggel nemzeti, faji, identitásbeli, világképi, hagyománykötött) áthatásokkal megküzdés problematikus mivoltát még olyan kiemelkedő személyiségek esetében is, mint Sík Sándor, Radnóti Miklós és Kecskeméti Ármin (életportré-értékủ bemutatásukat lásd Miklós 2014:

${ }^{17}$ Bővebben lásd: Szász 2013; Fényes 2012. 


\section{KÖZELKÉP - Hozzászólás}

211-221). Schőner Alfréd ugyanakkor arra is fölhívja a figyelmet, hogy a „soá felborította az Isten világrendjét", a holokauszt utáni demográfiai és korosztályi átrendeződés a politikai változásoktól függetlenül is átalakította „a - klasszikus értelemben vett család - a több, egymás mellett élő generáció - fogalmát” is: „tömegesen éltek túl szülők gyermekeket, (...) az új családok azonban nem a több évszázados társadalmi konvenciónak megfelelő korösszetételűek voltak" és így a tradicionális értékrend átadásában is sérült a szülő-gyermek kapcsolat, „egyedi attitűdök jelentek meg: az átlagosnál erőteljesebb szülői féltés, a megmagyarázható, de nem mindig logikusan következő túlzó gondoskodás. Az állandó jellegű óvatosság, traumát okozott a szülőnek és a gyermeknek egyaránt", eléggé hamar egyedül maradtak a fiatalok, „az érzelmi háttér, a vallástörténeti háttér, a hagyományos zsidó tradicionális háttér értelmében teljesen ismeretlen volt számukra." (Schőner 2014: 7, 2-73) Ezt később a vallásüldözés, a kettős nevelés időszaka követte, a titokban megvallott identitások és a tönkre ment tradíciók összhatása, a deportálást követő demográfiai gondok és a kényszerű migráció is nehezítették. A zsinagógák leromlottak, közösségeik szétszéledtek vagy a fővárosba költöztek, az eltérő haszid, ortodox és neológ vallásos gyakorlat „jelentős mértékben eltért attól az élettől, amit a mai fiatalok, a mai magyarországi - ateista nevelést kapott felnőttek - zsidó családjaiban láttak", a zsidó közösség tagjai sem voltak képesek kivonni magukat az össztársadalmi jelenségek hatása alól: „(csonkacsaládok, családok szétválása, politikai megosztottság, generációs érdekellentétek, esetlegesen drogproblémák, zűrzavar a közéletben és a fejekben egyaránt) mind-mind befolyásolják a 21. századi magyar zsidó család identifikációjának kérdéseit is." (Schőner 2014: 74-75) Mindezt követte a vallási ismeretek megfogyatkozása, az otthonból a zsinagógába szoruló hitélet, az elvilágiasodás, a klasszikus családmodell további átalakulása, a családok internetes távolságra szakadása, a hagyomány- és értékőrző kapcsolatok átértékelődése, a távolsági hitközösség jelenségének kialakulása is (uo. 75-76).

A túl messzi asszociációktól óvakodva, de nem mellőzve a kínálkozó szakirodalmat, érdemes meglátni a zsinagógai térből az otthonba, a súlból a privát életbe, majd a közösség újrakeresésekor a zsinagógai szakrális közösségbe visszatérők mentális modelljeit. Papp Richárd több kutatási szempontja (a nők szerepe, a humor és vicc-forma megoldások), vagy Vincze Kata Zsófia sokoldalú kutatása (2004, 2010, 2014) egyaránt rávilágít a generációs értelmezésmódok és mikroközösségi értékrendek párhuzamosságára, a háláchá értelmezéseire, az „átadó” korosztályok és az „átvevő” érzékenységek találkozási terepére. Ebben is megerősítő Rajkó Andrea kutatása, melyből a percepciós határok és a konvencionális szerephatárok sajátos interakciója is előviláglik: „kiderült az is, hogy a tabu megítélése nyilvánvalóan attól függött, hogy az adott válaszadó a saját mikrokörnyezetében (család, szülőhely, jelenlegi kortárscsoport) melyik témával és hogyan találkozott. A családi életet övező, már érvénytelennek tartott tabuk készlete nemcsak bőségesebb, hanem tartal- 


\section{KÖZELKÉP - Hozzászólás}

mában is kissé eltér a ma érvényes tabukétól. A fiatal generáció jóval kevésbé érzi tabunak a családi élet olyan aspektusait, mint a házasságtörés, a házasságon kívül született gyermekek, az élettársi kapcsolat, a nyitott házasság vagy az apás szülés kortárs tematikáit és társadalmi problematikáit, de persze számos olyan elem is akad, amelyet a kutatás 2010-2015 közötti időszakában sokan említettek, ugyanakkor jelen van a ma is érvényes tabuk között, melyeket a diákok ekként soroltak be (pl. válás, családon belüli erőszak, kapcsolati tabuk, vallással kapcsolatos megítélés, kisebbséggel, szexualitással kapcsolatos témakörök). A mai tabuk készlete, mint azt a kutatás során láttuk, a szexualitás témakörében volt a legbőségesebb, ez szerepelt legnagyobb súllyal a vizsgált korosztály életében és normarendjében." (Rajkó 2015: 101)

Nem lenne egykönnyen értelmezhető, ha a tabutörés, plafon- és üvegkalicka-törés kérdését pusztán a nemek közötti viszonyra, a szakrális konvenciók szigorúságára, az életvilág és értékrend megszabta mentális vagy morális környezeti kölcsönhatásokra próbálnánk visszavezetni a hagyomány-kitettség problematikáit. Az üvegplafon szimbolikus és egyben korlátozó léte nem puszta vízió, hanem a résztvevők és érintettek egy adott hányada szerint is megfogalmazható érzület. Akár csak olyan értelmezésmódokban is megjelenik ez, amely bár a feminizmustól sem mentes kritikai kommentárokban kap hangot, mégis jelez ennél mélyebb megosztottságot. „A nők szentírási ábrázolásáról és annak értelmezéséről jelen dolgozat óvatosan és csak röviden szól. Ugyanis a bibliai értelmező irodalmat és a kommentárokat főleg a férfiszerzők írták a hagyományosnak mondott családi és közösségi viszonyok igazolása és fenntartása érdekében. Ezért a nők bibliai társadalmi és családi státuszának kiderítésére ezek a munkák többnyire alkalmatlanak. Jelen diskurzus megvalósításához elsősorban a zsidó kulturális történeti leírásokhoz fordulok, amit feministaként kritikusan értelmezek. A tudományos feminizmus ugyanis megalapozza a nemek társadalmi helyzetének elemzését, és feltárja a nők társadalmi esélyeit. A talmudi szövegekből kikövetkeztethető, hogy a zsidó közösségi és családi magatartási előírások kialakulásának korában a nő társadalmilag az életet szabályozó előírások tárgyává vált. Ugyanis a férfi társadalom a tórai előírások saját értelmezése alapján rögzítette a háláchikus szabályokat. A mai zsidó nő - akár vallásos, akár nem - az aktuális önkép kialakításában a fentiekben említett háláchikus szabályok hagyományos, gyakorta ortodoxnak nevezett mintájából indul ki. Vagy úgy, hogy hátat fordít a rabbinikus hagyománynak, vagy újra értelmezi a férfiak által megfogalmazott előírásokat" (Hrotkó 2014: 51).

A hagyomány, minta-átvétel és családi modellek újkori történeti köre persze ennél árnyaltabb, miként azt Nagy Péter Tibor, Borbíró Fanni, Balogh Margit - S. Nagy Katalin, F. Dózsa Katalin, Karády Viktor és mások is részletesen áttekintik. Arra már Zima András hívja föl a figyelmet, hogy a modernizáló zsidó család miliőjében nem csupán a női, hanem a férfi szerepek is változásnak indultak: „a 19. század végére a 


\section{KÖZELKÉP - Hozzászólás}

20. század elejére a közép-európai polgári középosztálybeli zsidók számára a család jelentette az igazi értéket, és szimbolikus jelentéssel bírt. A modern középosztálybeli zsidók attól tartottak, hogy az új idők fokozatosan aláássák a zsidó családot. A család keretei között ment végbe a gyerek hasznos polgárrá nevelése. Marion Kaplan szerint ez különösen a kultúra területére volt igaz. Értelmezésében ebben a kulturális és társadalmi polgáriasításban volt kiemelt szerepe a zsidó nőnek. A nők tanították meg a gyerekeknek, a polgári viselkedés alapjait. Természetesen a kulturált középosztálybeli család, akkulturált zsidó családot is jelentett egyben. (...) Paula Hyman szerint, hogy a korai cionista vezetők gyakran vádolták elnőiesedéssel a középosztálybeli zsidó intelligenciát, és programként határozták meg az 'új zsidó' visszaférfiasítását, mind testben, mind lélekben." (Zima 2012)

A férfi „visszaférfiasítása” immár nyilvánvalóan nem századfordulós polgári értékképzet, de éppenséggel ezredfordulós. A nemek közötti kommunikáció, úgy is, mint a zsinagógai szakrális lét formája, s úgy is, mint az értékcsere jelképes tartománya a családi miliőben, akár tudás, akár gyakorlati ismeret, kósersági tájékozottság vagy a kapcsolati kötődés kitettségi mutatója, számos hétköznapi formában is megjelenik még: „A zsidó nők aktív részvételét a zsinagógai liturgiában az újkori rabbinikus hagyomány kb. 12. század óta erősen korlátozta. A nők kapcsolata a valláshoz az évek során változott, és új formákban jelent meg, például a női könyörgésekben (Techines) és a női kézimunkában. A női kézimunka az otthoni 'szakrális tér' kialakulását is lehetővé tette, ami a zsidó vallásosságnak egészen bensőséges vonásokat kölcsönöz. Azt is láthatjuk, hogy a nők a kézi munka formai sokaságában szívesen fejezték ki egyéniségüket, miközben a férfi liturgiát inkább az egységes szabályok szigorú megtartása jellemzi.” (Hrotkó 2014b: 5) „A női zsidó kézimunka mintegy láthatóvá teszi a zsidó hétköznapi és ünnepi imák szavaiban rejtett odaadás és hűség spiritualitását." (Hrotkó 2014b: 5-6)

\section{Összegzés}

E szerepek felfogása, követése, értelmezése és megjelenítése pedig - ez már előadásunk végét jelző, levezető kérdésfelvetés - nem bizonyosan van tekintettel a kortárs mobilitási szerepek, gender-mintázatok, korosztályi értékcélok kialakult rendszerére, melyek talán új és még újabb válaszokat sürgetnek a hívőközösségek fiatalabb generációi felől. Az itt felvetett témakörnek ez nem „kidolgozott” verziója, hanem csupán témává avatása, lehetséges problematikaként megosztása és vitára ajánlása volt célunk... A konferencia számos előadásában példaképpen megnevezésre vagy említésre került a zsidó női szerepfunkciók hagyományos jellegének megléte mint a családon, házon belüli szerepkör, szemben a férfiak külső, nyilvános megjelenésével, mely sokszor nem is leplezi a munkamegosztások térbeliségének, kapcsolati közelségnek vagy mindennapi szokásjogoknak megfeleltetését mint körülményt. Mind- 


\section{KÖZELKÉP - Hozzászólás}

ezek tehát még további és mélyebb elemzésre érdemes kérdések - de legalább nem eredendően érvénytelenek a kutatások tükrében. A címkézett alapkérdéseink tehát: hagyomány vagy modernitás, azaz konvencionális szerepek vagy siker-esélyesség, szerepkonvenciók a mobilitás-feszültséggel szemben, élethazugság vagy énkeresés, közösségi vagy társadalmi érvényesség, tabu-mentes adaptáció, vagy retardált szocializáció vár ma „a zsidó női” szerepváltozatokra?

A kiegyensúlyozott magyarázat, a következtetés tehát részint a kitettség és alárendeltség konvencióját rendeli a zsidó női szerepekhez, ezen belül pedig a kötelmek súlyos tömegéből fakadó egyenlőtlen állapot elfogadásához, s teszi ezt konvencionálisan, sőt értékrendi értelemben is, tehát a nő maradjon csak a család bűvkörében, ne tegye ki magát társadalmi-kapcsolati kötődéseknek, kísértéseknek és megaláztatásnak; másfelől pedig jobbára a fiatalabb korosztályoknál, melyeket a háláchikus hagyománykövetés már kevésbé jellemez, megjelenik és utat keres a kortárs családmodellek, rugalmasabb és kötetlenebb életvilágok fölfedezésének, megtalálásának kísérlete, melyek persze a társadalmi és a szakrális tabutörésnek egyaránt megfelelnek. A megfogalmazott vagy rejtett kérdések mögött helyenként persze trivialitások, eltérő szokások, változó normák, alkalmilag komolyan vett értékkészletek rejlenek, miképpen Glässer, Zima, Hrotkó árnyalja ezeket a történetiség, Vasvári a mozgalmiság példáival, de ott van még akkor Tóth Katalin, Papp Richárd, Hrotkó Larissza, Pécsi Katalin, Gantner B. Eszter, Vincze Kata Zsófia, Toronyi Zsuzsa, Kelemen Katalin megannyi válasza is, melyek a legkülönbözőbb válaszkísérletek példáival illusztrálják a mindenkori harmóniakeresés szándékát a kultúraközi mozgások között. Rajkó Andrea ugyanakkor vitatja, hogy itt specifikusan a zsidóság problematikájáról lenne szó, a létező plafonok és a tabutörések kísérletei más szakrális szférák nemi szerepköri, munkamegosztási, biológiai reprodukción túli állapotaiban egyaránt jelen vannak - akkor meg minek elkülöníteni a zsidóság saját megoldásait. Ugyanakkor pedig - véleményét osztva is, de árnyalni próbálva - az iszlámon belüli női mozgalmiság (nemcsak a Mediterránumban, hanem ázsiai változataiban is), valamint a genderen belüli kreatív kiterjeszkedési kísérletek más szakrális tartományaiban vagy formáiban is legfóképp az tükröződik, hogy a női válasz a szerepfunkciók kényszereire, ezek évezredes örökségére reflektál, de nem univerzális választ formál, hanem egyedit, kisközösségit, családit - így a problematika genderizálódási kimenetei csak egyféle aspektust, a kommunikált szerepfunkció-változást tükrözik (lásd ehhez Horváth Júlia Borbála „újnőkorszakának” tapasztalatát is), de egy továbbit Marom, Szochnut és az alternatív judaizmus megannyi más kísérlete segít értelmezni, és a családi-kisközösségi érdekérvényesítések egy újabb réteget formálnak, s minden további változat más-más egyéb kimenetet intézményesítenek vagy kínálnak fel.

E változatok és eseti elágazásaik sokfélesége miatt nem biztos, hogy valóban jó alapkérdés a zsidó női szerepkötöttségek és a virtuális vagy valóságos üvegplafonok ellentmondásossága. De nem biztos az sem, hogy ezek mondvacsinált változatok és a 


\section{KÖZELKÉP - Hozzászólás}

kérdés „rossz”. A rossz kérdésfeltevés ugyanis nem azzal/akkor fenyeget, ha egyféle sémát (akár az üvegplafon-törők új életfelfogási prioritását, akár a hagyománykötött viselkedési modellek kizárólagosságát) fogalmazunk univerzálisra, hanem ha nem tartjuk becsben a különféle válaszadási kísérleteket, vagy mesterkélt prioritásokat teszünk meg nóvumnak, „kívülről” átpozicionálva adott és lehetséges hatásaikat, kommunikatív értéktartományaikat... Úgylehet, a részválaszok esélyei nem megfosztják, inkább gazdagítják a válaszrepertoárt - erre legalább kísérletet tenni akkor is érdemes, ha az üvegkalicka falai talán mindig is körülöttünk vannak...

\section{Irodalom}

Angelusz, R. - Tardos, R. (2002): Társas kötelékek és kulturális tradíciók a magyar zsidóság különböző nemzedékeiben. In: Kovács, A. (szerk.): Zsidók a mai Magyarországon. Budapest, Múlt és Jövő.

Ausztrics, A. (2015): A maszorti zsidóság Magyarországon egy budapesti ifjúsági szervezet tükrében. In A. Gergely, A. - Papp, R. - Ausztrics, A. (szerk.): Zsidó kultúra és identitás - antropológiai nézőpontból. Tanulmányok a tematikus kutatásmódszertan köréból. Budapest, Antroport Könyvek.

Balogh, M. - S. Nagy, K. (szerk.) (2000): Asszonysorsok a 20. században. Budapest, BME Szociológia és Kommunikáció Tanszék, Szociális és Családvédelmi Minisztérium Nőképviseleti Titkársága.

Bódy, Zs. (2008): „A női munka felszabadítása vagy korlátozása”. A női eszmények változása, a női egyenjogúság konfliktusai és a női szervezetek állásfoglalásai a két világháború közötti középosztályban. In: Bakó, B. - Tóth, E. Zs. (szerk.): Határtalan nők. Kizártak és befogadottak a női társadalomban. Budapest, Nyitott Könyvműhely, 93-112.

Borbíró, F. (2007): Budapesti nőegyletek 1862-1904. In: Fábri, A. - Várkonyi, G. (szerk.): A nők világa. Művelődés- és társadalomtörténeti tanulmányok. Budapest, Argumentum Kiadó.

Borgos, A. (2013): Nemek között. Nötörténet, szexualitástörténet. Budapest, Noran Libro.

Cseh, E. (2015): „Minden játék a férfiaknak jut!”. Női szerepek egy párizsi zsinagógában. In: A. Gergely, A. - Papp, R. - Ausztrics, A. (szerk.): Zsidó kultúra és identitás antropológiai nézőpontból. Tanulmányok a tematikus kutatásmódszertan köréböl. Budapest, Antroport Könyvek.

Czeferner, D. (2014): „Kávéházakban, klubokban, olvasókörökben kérjük $A$ Nő és a Társadalom lapot!" 


\section{KÖZELKÉP - Hozzászólás}

Egy folyóirat a nők egyenjogúságáért. Médiakutató, nyár, 49-61.

Dalsace, Y. (2006): La place de la femme dans le rituel synagogal. On-line: http:// www.massorti.com/La-place-de-la-femme-dans-le.html utolsó letöltés dátuma: 2019. 01. 22.

Fényes, B. (2018): „Családjaik, atyai házaik szerint...” Adalékok a rabbinikus zsidó hagyomány családképéhez. In: Barna, G. - Kiss, E. (szerk.): Családtörténet, családvédelem, vallás. A család egykor és ma, 4. kötet, A vallási kultúrakutatás könyvei 37. Szeged - Budapest, MTA-SZTE Vallási Kultúrakutató Csoport - OR-ZSE Kaufmann Dávid Kutatócsoport, 60-67.

Fényes, B. (2012): Kitalált hagyomány - egy mítosz kitalálása. In: „Őrizzétek meg órizetemet..." Tanulmányok a rabbinikus hagyomány köréből. Budapest, Jószöveg Mühely Kiadó, 207-239.

Fenyves, K. (2012a): A magyar zsidó nő - a felekezeti sajtó nőképe a 19-20. század fordulóján. In: Bíró Zs. H. - Nagy P. T (szerk.): Zsidóság - tradicionalitás és modernitás. Tisztelgő kötet Karády Viktor 75. születésnapja alkalmából. Wesley János Lelkészképző Főiskola, Budapest, 105-118. On-line: www.mek.oszk. hu/11600/11687/11687.pdf utolsó letöltés dátuma: 2019.01.22.

Fenyves, K. (2012b): Zsidó polgáriasodás a 19-20. század fordulójának Magyarországán: a nyelvhasználat és nők helyzetének alakulása. Habilitációs értekezés. Budapest, Országos Rabbiképző - Zsidó Egyetem.

F. Dózsa, K. (1991): Pesti nő a századfordulón. Nőkérdés: feminin vagy feminista. Rubicon 3. On-line: http://www.rubicon.hu/magyar/oldalak/pesti_no_a_szazadfordulon_nokerdes_feminin_vagy_feminista/ utolsó letöltés dátuma: 2019.01.22.

Glässer, N. (2015): Az opera tündérei vagy a sábesz angyalai? Nosztalgikus vagy normatív vidéki zsidó élet képe a budapesti magyar nyelvű orthodox sajtóban. In: Barna, G. - Kiss, E. - Gyöngyösi, O. (szerk.): A család egykor és ma. Szeged Budapest, MTA-SZTE Vallási Kultúrakutató Csoport - OR-ZSE Kaufmann Dávid Kutatócsoport, 166-178. On-line: www.pointernet.pds.hu/kissendre/judaisztika/3-2015A_csalad_egykor_es_ma.pdf utolsó letöltés dátuma: 2019.01.22.

Glässer, N. - Zima A. (szerk.) (2014): Hagyományláncolat és modernitás. SZTE Néprajzi és Kulturális Antropológiai Tanszék, Szeged.

Glässer, N. (2012): Ateresz z'kénim. A vallási szocializáció családképe a két világháború közötti budapesti orthodox zsidó sajtó diskurzusaiban. In: Csipak Á. (szerk.): Pléróma (1947-2012) dr. Rokay Zoltán 65. születésnapján szabadkai, óbecsei és budapesti tanítványai. Lux Color Printing - Szulik Alapítvány, Óbecse, 77-108. On-line: http://publicatio.bibl.u-szeged.hu/2753/7/2217258.pdf 


\section{KÖZELKÉP - Hozzászólás}

Gleszer, N. (2010): Tórájának fele... A rabbiné és a zsidó nő imagológiája a magyar nyelvű budapesti orthodox zsidó sajtóban a 19. század végén és 20 . század elején. In: Filko V. - Kőhalmy N. - Smid B. (szerk.): Voigtloristica. Tanulmányok a 70 éves Voigt Vilmos tiszteletére. Folcloristica 11. Budapest, ELTE - BTK Folklóre Tanszék.

Guiliano, M. (2010): A francia nők karriert csinálnak. Munka, értelem és érzelem. Budapest, Athenaeum.

Gyáni G. - Nagy B. (szerk.) 2006 Nők a modernizálódó magyar társadalomban. Debrecen, Csokonai Kiadó.

Horváth, J. B. (2008): Újnőkorszak - Intermentalitás a XX. század második felétől Magyarországon. Budapest, L’Harmattan.

Hrotkó, L. (2014a): Családi státuszok a T’nach és a talmudi irodalom alapján. In: Barna G. - Kiss E. - Gyöngyösi O. (szerk.): A család egykor és ma. MTA-SZTE Vallási Kultúrakutató Csoport - OR-ZSE Kaufmann Dávid Kutatócsoport, Szeged - Budapest, 51-59. On-line: www.pointernet.pds.hu/kissendre/judaisztika/3-2015A_ csalad_egykor_es_ma.pdf

Hrotkó L. (2014b) Pirké Imahot. Kézimunka a feminizmus és a vallás szolgálatában. Hacofe, Vol 9. https://or-zse.hu/hacofe/vol9/hrotko.pdf

Hrotkó, L. (2014c): A nélkülözhetetlenek. A zsidók 18. századvégi - 19. század eleji letelepedése Pesten különös tekintettel a zsidó nők helyzetére. OR-ZSE, Budapest. On-line: https://www.or-zse.hu/javne/larissza3.pdf; http://mek.oszk.hu/ $13500 / 13596$

Hrotkó, L. (2012): Családi viszonyok a talmudi régészetben, különös tekintettel a nők és a gyerekek családi státuszára. http://www.or-zse.hu/hacofe/vol4/ hrotko-csaladiviszonyok-zsidocsalad2012.htm

Huszár Á. (2011): A nő terei. Budapest, L'Harmattan Kiadó.

Karády, V. (1993): A vegyes házasságok Budapesten 1950 előtt. Néhány kutatási eredményről. Múlt és Jövő, 3: 82-84.

Kende, A. (szerk.): 2008 Pszichológia és feminizmus. Budapest, L'Harmattan.

Kelemen, K. (2012): Visszaadni Istennek elvesztett szövetségesét. In: Biró Zs. H. Nagy P. T. (szerk.): Zsidóság - tradicionalitás és modernitás. Tisztelgő kötet Karády Viktor 75. születésnapja alkalmából. Wesley jubileumi kötetek, 9. Wesley János Lelkészképző Főiskola, Budapest 461-471. On-line: www.mek.oszk. hu/11600/11687

Kelemen, K. (2002): A liberális judaizmus álláspontja a nők szerepéről a zsidóságban. In: Toronyi, Zs. (szerk.): A zsidó nő. Magyar Zsidó Múzeum és Levéltár, Budapest, 143-145. 


\section{KÖZELKÉP - Hozzászólás}

Kiss, E. - Barna, G. (2014): Ajánló szavak. In: Barna, G. - Kiss, E. (szerk.): A család egykor és ma. Gyöngyössy O. közreműködésével. Szeged - Budapest. SZTE BTK Néprajzi és Kulturális Antropológia Tanszék - OR-ZSE Kaufmann Dávid Zsidó Kultúratudományi Kutatócsoport.

Küllős, I. (szerk.) (1999): Hagyományos női szerepek. Nők a populáris kultúrában és a folklórban. Budapest. Magyar Néprajzi Társaság, Szociális és Családügyi Minisztérium, Nőképviseleti Titkárság.

Mars, L. (1999): Discontinuity, Tradition and Innovation: Anthropological Reflections on Jewish Identitv in Contemporary Hungary. Social Compass, 46 (1): 21-33.

Maybaum, Zs. (1884): A nő állása a bibliai ókorban. Magyar-Zsidó Szemle, 488-493.

Mikes, H. (2013): „Azért mindig a nő irányít” - a hagyományos zsidó női szerepek megjelenése egy zsinagóga közösségében. OTDK-dolgozat, ELTE TÁTK, Kulturális Antropológia Tanszék.

Miklós, P. (2014): Az identitásszerveződés kérdései a magyar zsidó polgárcsaládokban. In: Barna, G. - Kiss, E. - Gyöngyösi, O. (szerk.): A család egykor és ma. MTASZTE Vallási Kultúrakutató Csoport - OR-ZSE Kaufmann Dávid Kutatócsoport, Szeged - Budapest, 211-221.

Modla, Zs. (2007): Mai magyar zsidó fiatalok szocializációja. In: A. Gergely, A. - Papp, R. (szerk.): A szakralitás arcai. Nyitott Könyvműhely, Budapest, 269-297.

Nagy, P. T. (2015): Az egyetemisták, a szüleik és a zsidó nem-zsidó vegyesházasság. Iskolakultúra, 3:47-55. On-line: https://matarka.hu/klikk.php?cikkmutat= 2205320\&mutat=http://epa.oszk.hu/00000/00011/00193/pdf/EPA00011_iskolakultura_2015_03_047-055.pdf utolsó letöltés dátuma: 2019.01. 22.

Nagy, P. T. (2010): Egy ortodox zsidó közösség a helyi társadalomban. Iskolakultúra, 7-8: 84-94.

Németh Vályi, K. (2016): „Soha semmilyen előítélet nem ledönthetetlen”. Szombat, május 21. https://www.szombat.org/politika/soha-semmilyen-eloitelet-nem-ledonthetetlen utoló letöltés dátuma: 2019. 01. 22.

Oláh, J. (2015): A zsinagógáról és szokásairól. Yerusha, „KINDERJOHREN”, on-line: http://www.yerushaonline.com/?v=di11pla34 utolsó letöltés dátuma: 2019.01. 22.

Papp, M. (2007): „Mécsese az Örökkévalónak az ember lelke”. A visszatérés és a sábesz kapcsolatának jelentései egy budapesti ortodox zsidó közösségben. In: A. Gergely, A. - Papp, R. (szerk.): A szakralitás arcai. Vallási kisebbségek, kisebbségi vallások. Budapest, Nyitott Könyvmühely, 314-361.

Papp, R. (2004): Van-e zsidó reneszánsz? Kulturális antropológiai válaszlehetőségek egy budapesti zsidó közösség életének tükrében. Budapest, Múlt és Jövő Kiadó. 


\section{KÖZELKÉP - Hozzászólás}

Papp, R. (2002): A nők világa egy budapesti zsinagógában. In: Toronyi Zs. (szerk.) A zsidó nő. Magyar Zsidó Múzeum és Levéltár, Budapest, 137-141.

Pécsi, K. (2009): A szenvedés neme. Női tapasztalat, női hang. In: Gantner, B. E. Réti, P. (szerk.) Az eltűnt hiány nyomában. Az emlékezés formái. Budapest, Nyitott Könyvműhely, 134-150.

Pécsi, K. (szerk.) (2007): Sós kávé. Elmeséletlen női történetek. Budapest, Novella Kiadó.

Pécsi, K. (szerk.) (2013): Lányok, anyák. Elmeséletlen női történetek. Budapest, Novella Kiadó.

Rajkó, A. (2016a): Tabu, tabudöntés, tabuizálás. Kultúra és Közösség, 1:91-109. On-line: http://www.kulturaeskozosseg.hu/pdf/2016/1/08.pdf utolsó letöltés dátuma: 2019.01.22.

Rajkó, A. (2016b): Kommunikációs tabuk kutatása. Módszertani megfontolások és kihívások. Közelítések (3) 1-2: 36-131. Budapest, Zsigmond Király Főiskola.

S. Nagy, K. (2006): Emlékkavicsok. Holokauszt a magyar képzőművészetben 19381945. Budapest, Glória Kiadó.

Schőner, A. (2014): Az újrasarjadzó zsidó élet a feszültségek forrásává is vált... A zsidó család a 21. század elején Magyarországon. In: Barna, G. - Kiss, E. (szerk.): A család egykor és ma. Gyöngyössy 0. közreműködésével Szeged - Budapest, SZTE BTK Néprajzi és Kulturális Antropológia Tanszék - OR-ZSE Kaufmann Dávid Zsidó Kultúratudományi Kutatócsoport, 72-77.

Schweitzer G. (2016) „Haladó zsidóság - halódó zsidóság”? Útkeresés egykor és ma. Szombat, 10. On-line: https://www.szombat.org/politika/schweitzer-gabor-halado-zsidosag-halodo-zsidosag

Szász, A. (2013): Női rabbik a zsidóságban. Axis, 1: 83-99.

Szász, A. (2011): Alternatív zsidóság. A Bét Orim Reform Zsidó Közösség. Kisebbségkutatás, (20) 4: 550-583.

Szász, A. (2008): A progresszív judaista mozgalom és a tradicionális zsidó értékek és normák. A hazai mozgalom ideológiája és gyakorlata által indukált társadalmi diskurzus, egyéni és intézményi reflexiók. In: S. Nagy, K. - Szász, A. (2002): Parázs. A magyar asszimilált zsidóság útkeresése. I. Szim Salom Progresszív Zsidó Közösség. Etnoregionális Munkafüzetek 87. (Sorozatszerk. A. Gergely A.). Budapest, MTA PTI.

Orbán, A. (szerk.) Értékek és normák interdiszciplináris megközelítésben. Budapest, Gondolat Kiadó.

Tillmann, L. E. (2009): Zsidó gyermeknevelés Budapesten. Előadás a Folytonosság, szakadás, reneszánsz? konferencián (MTA PTI Etnoregionális Kutatóközpont, 2008. január 18.) 


\section{KÖZELKÉP - Hozzászólás}

Tóth, A. (2015): Tradicionalitás és innováció - a vallástudomány és a neveléstudomány határán - a zsidó nevelésben. PhD disszertáció, OR-ZSE, Zsidó Vallástudományi Doktori Iskola. Budapest. On-line: https://www.or-zse.hu/phd/TothAndrea_PhD_disszertacio_javitott_15_06_15.pdf utolsó letöltés dátuma: 2019. 01. 22.

Vincze, K. Zs. (2014) Hagyomány és poszt-tradicionalizmus - a magyarországi zsidóság hagyományértelmezései. In: Glässer N. - Zima A. (szerk.) Hagyományláncolat és modernitás. Szeged, SZTE Néprajzi és Kulturális Antropológiai Tanszék, MTASZTE Vallási Kultúrakutató Csoport, 303-316.

Vincze, K. Zs. (2013): Conversio és etnicitás a mai magyarországi zsidóságban. In Conversio. Az Eötvös Loránd Tudományegyetem Bölcsészettudományi Karán 2011. szeptember 22-23-án tartott vallástudományi konferencia előadásai. Eötvös Loránd Tudományegyetem Bölcsészettudományi Kar Vallástudományi Központ, 149-154. On-line: http://archive.jpr.org.uk/object-hun38

Vincze, K. Zs. (2010): Visszatérők a tradícióhoz. Budapest, L’Harmattan.

Vincze, K. Zs. (2004): Tradíció, emlékezés, értelmezés. Az egyiptomi kivonulás-történet értelmezése a mai budapesti zsidóság vallásos jelenségeiben. Etnoregionális Munkafüzetek 94. (Sorozatszerkesztő A.Gergely A.) Budapest, MTA Politikai Tudományok Intézete Etnoregionális Kutatóközpont.

Zima, A. (2012): „A zsidóságért és a zsidó gyermekekért”. (Zsidó nemzeti családmodell a budapesti cionista sajtóban a 20. század első felében). Hacofe, Vol. 4. OR-ZSE, https://or-zse.hu/hacofe/vol4/zima-azsidosagert-zsidocsalad2012.htm. Utolsó letöltés dátuma: 2019. 01. 22.

\section{További (online) források}

A Talmud ötven árnyalata... In Savout éjszakája, NŐ ÉS FÉRFI, Bálint Ház 2017. május 30. Büchler Tamás Minyanim programigazgató (Szochnut), on-line: http:// www.mazsihisz.hu/2016/03/23/-a-talmud-otven-arnyalata--es-a-kozepkori-zsido-feminizmus-8644.html

Caddik Messiáshívő Tanítások, http://csalad-gyulekezet.5mp.eu/

Emet Ve'emunah: Statement of Principles of Conservative Judaism. https://www.scribd.com/document/3491343/emet-ve-emunah-statement-of-principles-of-conservative-judaism

Grottó Mór 1916 A zsidó gyermeknevelés problémája. Zsidó Szemle, július 14./2-3.

Magyar zsidó női életutak, http://zsidonok.hu/

Női Karrierfejlesztési Szövetség, http://www.noikarrier.hu/

Raj Tamás weboldala, http://www.zsido.hu/ 
www. metszetek.unideb.hu

\section{KÖZELKÉP - Hozzászólás}

Savout - a Bálint Ház Éjszakája, 2018. http://web.balinthaz.hu/Event/savuot_a_balint_haz_ejszakaja_itthon_otthon_haza_2018-05-19

Szombat hetilap, „Keresd a nőt” https://www.szombat.org/tag/2014-02

Verő/Bán Linda, a Frankel Leó utcai zsinagóga rebecenje válaszol kérdéseitekre és mesél a nők helyzetéről a zsidó házakban, otthonokban, http://frankel.hu/category/gyerekeknek/

Yerusha /OR-ZSE/ http://www.yerushaonline.com/

Zsidó Szemle, 1917. december 14./1-2. Igazi nacionalista lányok. 